\title{
Internationale parentale ontvoering en conflictde-escalatie in het belang van het kind
}

\author{
Elise Blondeel
}

\section{Inleiding}

Wanneer ouders in een conflict terechtkomen, heeft dit onvermijdelijk ook een impact op hun kinderen. Deze impact hoeft geenszins verontrustend te zijn, gezien conflicten nu eenmaal behoren tot het dagelijkse leven en nodig zijn voor het aanleren van constructieve manieren van conflicthantering. In bepaalde gevallen kan het ouderlijk conflict echter zodanige proporties aannemen, dat het belang van het kind sterk onder druk komt te staan. De specifieke casus van parentale ontvoering, waarbij een van beide ouders het kind onrechtmatig meeneemt naar, of achterhoudt in, het buitenland, is een voorbeeld van een dergelijke situatie.

Op het ogenblik dat het belang van het kind totaal ondergraven dreigt te worden, is het belangrijk dat de bevoegde overheden ingrijpen. Het gegeven dat ouders de primaire opvoedingsverantwoordelijken zijn voor de kinderen mag geen vrijgeleide zijn voor het nalaten in te grijpen wanneer het strikt noodzakelijk is voor het waarborgen van het welzijn van de betrokken kinderen. De overheid dient dan haar verantwoordelijkheid als belangenbehartiger op te nemen.

Grosso modo hebben de bevoegde overheden twee strategieën voor conflicthantering ter beschikking: enerzijds bemiddeling en anderzijds gerechtelijke procesvoering. De centrale onderzoeksvraag in deze bijdrage luidt als volgt:

In welke mate kunnen de wijzen van conflictbeslechting - in de Belgische context geoptimaliseerd worden zodat het belang van het kind gewaarborgd blijft, in het licht van de theoretische inzichten die de conflicttheorie van Glasl aanreikt?

Om deze vraag te beantwoorden werd een omstandige literatuurstudie gedaan, waarbij de focus van de deskresearch lag op de conflicttheorie van Glasl. De verantwoording voor de keuze van de casus van parentale ontvoering is samen te vatten in drie argumentatielijnen. In wat volgt, zullen eerst en vooral deze argumentatielijnen behandeld worden in de respectievelijke eerste drie delen van deze bijdrage. Vervolgens zullen de inzichten die de conflicttheorie van Glasl met zich meebrengen onder de loep genomen worden. Daarbij zal nagegaan worden wat de implicaties zijn van de positie van de conflictpartijen op de ladder voor de (on)mogelijkheid tot de-escalatie in de casus van parentale ontvoering. 


\section{Onrustwekkende stijging van internationale parentale ontvoering}

Een eerste verantwoording voor de keuze van de casus van internationale parentale ontvoering schuilt in de significante stijging van de prevalentie van het fenomeen. Het recente jaarrapport van Child Focus toont aan dat het fenomeen het laatste jaar een onrustwekkende stijging gekend heeft in België van maar liefst 10\%. In concrete cijfers vertaalt zich dat naar een indrukwekkend cijfer van 257 behandelde ontvoeringen in België, inkomend dan wel uitgaand. ${ }^{1}$ Het bericht haalde onmiddellijk de krantenkoppen en beleidsinitiatieven werden opgestart. Voordien kreeg internationale parentale ontvoering, al jarenlang een prioriteit voor Child Focus, niet dezelfde status op beleidsniveau.

De stijging kan in verband gebracht worden met twee tendensen in de huidige samenleving.

Een eerste verklarende factor voor de stijgende trend is de toename van het aantal interculturele huwelijken. Globalisering en onbeperkte mobiliteit zijn kenmerkende eigenschappen voor de hedendaagse maatschappij. Een logisch gevolg daarvan is dat liefdesrelaties niet stoppen aan de landsgrens. Het aantal gemengde huwelijken, gedefinieerd als een huwelijk tussen een Belgische echtgenoot en een echtgenoot met een andere nationaliteit, stijgt jaar na jaar. In 2017 werden 17,4\% van alle huwelijken als intercultureel benoemd. ${ }^{2}$

Ten tweede speelt het grote aantal vechtscheidingen een belangrijke verklarende rol bij de stijgende prevalentiecijfers. Het aantal scheidingen dat getypeerd wordt als hoog-conflictueus, wordt geschat op $36 \%$ en maar liefst $50 \%$ van alle kinderen ervaart de ouderlijke scheiding als een ware vechtscheiding. Het is een opmerkelijk gegeven dat ouders hun gedrag positiever blijken in te schatten dan de wijze waarop het daadwerkelijk wordt ervaren door de betrokken kinderen. ${ }^{3}$

Het hoeft geen betoog dat bij het beëindigen van een interculturele relatie bemoeilijkende factoren komen kijken. Het vinden van een gepaste verblijfsregeling voor de kinderen is daarbij een cruciaal aspect. Wanneer het onmogelijk blijkt tot een overeenkomst te komen, schuilt het gevaar van internationale parentale ontvoering om de hoek. In de literatuur worden deze ontvoeringen dan ook meermaals benoemd als schaduwkant van de toegenomen mobiliteit en globalisering. ${ }^{4}$ De toename in enerzijds het aantal interculturele huwelijken en anderzijds het aantal vechtscheidingen zorgt ervoor dat het aantal gezinnen met verhoogde kwetsbaarheid voor parentale ontvoeringen toeneemt.

1 Child focus. Jaarverslag 2017, Brussel: Europees centrum voor vermiste en seksueel uitgebuite kinderen.

2 StatBel. (2018). Echtscheidingen: Belg trouwt steeds later en scheidt steeds minder, 6 november 2018, geraadpleegd op 28 december 2018 op https://statbel.fgov.be/nl/themas/bevolking/ huwelijken-en-echtscheidingen/echtscheidingen.

3 K. Bastaits, C. Van Peer \& D. Mortelmans, Hoe beleven partners en kinderen een echtscheiding?, in: D. Mortelmans e.a. (red.), Scheiding in Vlaanderen, Leuven: Acco 2011; C. Wiewauters \& K. Emmery, Awel, ik ben in de war door de scheiding van mijn ouders, 2016.

4 T. Kruger, International child abduction: the inadequacies of the law, Londen: Bloomsbury Publishing 2011. 


\section{Kinderen worden slachtoffer van strijdende ouders}

Een tweede verantwoording voor de keuze voor parentale ontvoering als casus verwijst naar het gegeven dat conflicthantering in deze zaken een belangrijke achterliggende doelstelling heeft: het vrijwaren van het belang van het kind. In onderstaande sectie wordt aangetoond dat het kind in een precaire situatie terechtkomt, wanneer het conflict zodanig escaleert dat een van beide ouders autonoom beslist het kind te ontvoeren.

De bevoegde overheden moeten dan ook aangesproken worden op hun verantwoordelijkheid in het voorzien van een adequate methode van conflictbeslechting in deze zaken. Secundair slachtofferschap van de kinderen, door de wijze waarop met hun betrokkenheid in het conflict omgegaan wordt, moet te allen tijde vermeden worden. Doelstelling is dan ook om de conflicthanteringsmethoden te optimaliseren, de belangen van de kinderen indachtig.

\section{Probleemstelling: belang van het kind in de knel}

Kinderen kunnen (on)gewild slachtoffer worden van de strijd die heerst tussen beide ouders. Wanneer deze laatsten beslissen een punt te zetten achter hun relatie, beïnvloeden ze daarmee ook onvermijdelijk de kinderen. Uitdaging daarbij is om de kinderen niet op actieve wijze te betrekken in de conflictueuze scheiding. Vanuit het systeemdenken wordt een gezin vaak voorgesteld als een micro-organisatie, een soort bewegend mobiel dat door vaste posities, rollen, verhoudingen en verwachtingen een evenwichtige balans heeft bereikt. Een scheiding brengt abrupt een einde aan dit evenwicht. Onderzoek toont aan dat de gemiddelde aanpassingstijd voor kinderen twee tot drie jaar bedraagt. Na dit tijdsverloop functioneren de kinderen weer volop vanuit veerkracht. Wiewauters duidt deze transitie door het gebruik van concentrische cirkels die de comfort-, stretch- en stresszone representeren. Streven is om niet in de stresszone, ook wel paniekzone genoemd, terecht te komen en na de aanpassingstijd in de stretchzone idealiter terug de comfortzone te bereiken. ${ }^{5}$

Academici en praktijkactoren hebben aangetoond en herbevestigd dat een vechtscheiding een risicofactor is voor de gezonde ontwikkeling van een kind. ${ }^{6}$ De energie die gebruikt wordt om zich te handhaven in voortdurend conflict kan niet langer geïnvesteerd worden in een normale ontwikkeling, waardoor deze een vertraagd of ongezond verloopt kent. Bij een 'normale' echtscheiding blijft het ontwikkelingskapitaal haast altijd overeind. Ook een conflictueuze scheiding hoeft de ontwikkeling van een kind niet te doorkruisen, waar een ware 'vechtscheiding' dat wel doet. ${ }^{7}$ Deze twee laatste vormen van echtscheiding onderscheiden zich op een belangrijk punt van elkaar. In het eerste geval slagen de ouders erin het conflict te beperken tot hun relatie op partnerniveau. In het tweede geval wordt het conflict

5 C. Wiewauters, Webinar: Mag ik ook wat zeggen?, Gezinsbond, op 19 november 2018.

6 C.B. Garrity \& M.A. Baris, Caught in the middle: Protecting the children of high-conflict divorce. New York: Lexington Books 1994.

$7 \quad$ K. Bastaits, C. Van Peer \& D. Mortelmans, Hoe beleven partners en kinderen een echtscheiding?, in: D. Mortelmans e.a. (red.), Scheiding in Vlaanderen, Leuven: Acco 2011. 
doorgetrokken naar hun relatie op ouderniveau en wordt zodoende het belang van de kinderen uit het oog verloren. Eén of beide ouders verlaten hun ouderpositie en gaan volledig op in het strijdverhaal tussen zichzelf en de ex-partner. Het veiligheidsgevoel van het kind wordt in deze vaak jarenlang durende strijd volledig tenietgedaan. ${ }^{8}$

Het spreekt voor zich dat het kind door de ontvoering actief betrokken geraakt en zelfs misbruikt wordt. Deze heftige gebeurtenis ontneemt het cruciale veiligheidsgevoel op een zeer dwingende manier aan het kind. Het gezin, en specifiek het kind, bevindt zich tijdens de ontvoering onvermijdelijk in de stresszone.

\section{Escalerend conflict: de gevolgen voor de kinderen}

Wanneer het kind wordt ontvoerd, is vaak een eindpunt bereikt van een conflictcontinuüm, dat start bij een hanteerbaar conflict, ontspoort over een vechtscheiding en uiteindelijk uitmondt in een daadwerkelijke ontvoering.

Eerst en vooral is het belangrijk voldoende nuance aan te brengen in het debat over de relatie tussen een ouderlijke vechtscheiding en ontwikkelingsproblemen bij kinderen. Onenigheid heerst over het bestaan van een eenduidige causale relatie tussen beide factoren. Waar wel consensus over bereikt is, is het feit dat een reeks complexe, interagerende en elkaar versterkende negatieve factoren hun oorsprong vinden in de vechtscheiding. ${ }^{9}$

Aan de basis van de emotionele moeilijkheden waarmee kinderen van vechtende ouders te maken krijgen, ligt het loyauteitsconflict. ${ }^{10}$ Loyauteit is een diep geworteld innerlijk gegeven, een vanzelfsprekende stroom van liefde en genegenheid tussen ouders en kinderen. Het wordt omschreven als een gecombineerd gevoel van verbondenheid en trouw dat automatisch in gelijke mate aanwezig is voor moeder en vader. Het hoeft geen uitleg dat een ontvoering het gevoel van loyauteit op zeer dwingende manier onder druk zet en het kind onthecht kan geraken van een van beide ouders. ${ }^{11}$ Het kind wordt letterlijk weggerukt uit de vertrouwde omgeving en contact met de achtergebleven ouder wordt onmogelijk, minstens sterk bemoeilijkt. Deze fysieke scheiding bakent de loyauteit op een kunstmatige manier af. Bij meegaandheid met de ontvoerende ouder voelt het kind zich trouw tegenover deze ouder, wat in deze fase van het conflict onvermijdelijk ontrouw ten opzichte van de andere ouder betekent. Het hebben van een gespleten loyauteit is een factor die de persoonlijke ontwikkeling van het kind kan afremmen. ${ }^{12}$

8 N.M. Bing, W.M. Nelson III \& K.L. Wesolowski, Comparing the effects of amount of conflict on children's adjustment following parental divorce, Journal of Divorce \& Remarriage 2009, 50(3), p. 159-171; L. De Laet \& R. Van De Voorde, Kinderen als wapen en prooi in vechtscheidingssituaties, Signaal 2010(71), p. 4-25; L. Driesen, Ik wil mama én papa, allebei: over echtscheiding, verwerking, loyaliteit en hulpverlening, Antwerpen: Garant 2012.

9 P.R. Amato, The consequences of divorce for adults and children, Journal of Marriage and Family 2000(62), p. 1269-1287.

10 L. Driesen, Ik wil mama én papa, allebei!: over echtscheiding, verwerking, loyaliteit en hulpverlening, Antwerpen: Garant 2012.

11 C. Wiewauters \& M. Van Eyken, Een week mama een week papa?, Tielt: Lannoo 2014.

12 Ibid. 
In extreme gevallen mondt dit loyauteitsconflict uit in kindermishandeling, waarbij het kind emotioneel mishandeld of verwaarloosd wordt. ${ }^{13}$

Twee veelvoorkomende gevolgen van zulke mishandeling zijn de fenomenen van oudervervreemding en parentificatie. Dit laatste betekent dat het kind zodanig veel verantwoordelijkheid draagt, dat het verwacht wordt te functioneren als ouder in de relatie. In de casus van parentale ontvoering neemt echter vooral het eerste fenomeen een belangrijke plaats in. Niet zelden lijden ontvoerde kinderen aan oudervervreemding. De oorzaak daarvan ligt in het gedrag van de ontvoerende ouder, die alles in het werk stelt opdat het kind de andere ouder evenzeer zal haten als hij- of zijzelf doet. Finaal kan dit leiden tot radicale ouderverstoting, waarvan de negatieve consequenties niet te overzien zijn. ${ }^{14}$ Niet enkel tast dit de identiteit van het betrokken kind aan, het kan daarenboven leiden tot zowel internaliserend als externaliserend probleemgedrag. Sommigen gaan zelfs zo ver te stellen dat het ervaren van een vechtscheiding een criminogene invloed heeft op het ontwikkelen van delinquent gedrag. ${ }^{15}$

Het is duidelijk dat de wortels van het kind aangetast worden door een parentale ontvoering. Kinderen dragen immers altijd een stukje van beide ouders in zich. Wanneer de ene ouder de andere afwijst en het kind hierdoor de verbondenheid met deze ouder ontkent, ervaart het dus ook een stukje afwijzing van zichzelf. ${ }^{16}$

\section{Gebroken partnerrelatie en gebarsten ouderrelatie}

$\mathrm{Nu}$ duidelijk is dat een parentale ontvoering de gezonde ontwikkeling van een kind kan doorkruisen, moet op zoek worden gegaan naar manieren om dit risico te beperken. In het ontwikkelen en vinden en ook ontwikkelen van methoden om het conflict op een adequate manier te hanteren, is het cruciaal dat een fundamenteel onderscheid gemaakt wordt tussen twee relaties van de conflictpartijen: enerzijds de relatie op partnerniveau en anderzijds de relatie op ouderniveau.

Waar in de situatie van een parentale ontvoering een einde gemaakt werd aan de eerste relatie, zal de tweede relatie nooit ophouden te bestaan. In de context van een parentale ontvoering is het duidelijk dat beide partners te ver van elkaar verwijderd zijn om nog tot verzoening te komen. Daarover moet duidelijkheid geschept worden, zodat het kind geen valse hoop op hereniging koestert en gevoelens van onzekerheid en machteloosheid tot een minimum worden beperkt. Dit is echter een noodzakelijke maar onvoldoende voorwaarde voor het herstellen

13 L. De Laet \& R. Van De Voorde, Kinderen als wapen en prooi in vechtscheidingssituaties, Signaal 2010(71), p. 4-25.

14 R.A. Gardner, The parental alienation syndrome: A guide for mental health and legal professionals. Creative therapeutics 1998; C. Wiewauters \& K. Emmery, Parental Alienation Syndrome of contactbreuk. Waarom uit het oog niet uit het hart is. Kinderen verst(r)ikt in verbinding, Relaties en Nieuwe Gezinnen 2016, 6(2), p. 1-29.

15 J. Laub \& R. Sampson, Shared Beginnings, Divergent Lives: Delinquent Boys to Age 70, Cambridge/London: Harvard University Press 2003: M.G.A. Van de Rakt, Parental divorce in criminal families: a second test of static and dynamic theories of crime. Two Generations of Crime: The Intergenerational Transmission of Criminal Convictions over the Live Course, Nijmegen: Ipskamp 2011.

16 C. de Ruiter, In dialoog over conflictscheidingen, Dth: kwartaalschrift voor directieve therapie en hypnose 2016, 36(1), p. 62-67. 
van het veiligheidsgevoel bij het kind. De doorslaggevende factor voor het ervaren van dit gevoel, vanwaaruit een gezonde hechting zich kan ontwikkelen, is de bevestiging dat beide ouders hun ouderrol in een gezamenlijke verantwoordelijkheid zullen blijven vervullen. Een doorleefde invulling van hun ouderrol bevordert met andere woorden het welzijn van het kind. ${ }^{17}$

Samengevat kan gesteld worden dat de conflictpartijen voor de uitdaging staan hun conflict te beperken tot het niveau van hun partnerrelatie en te vermijden dat dit op schadelijke wijze doorvloeit tot hun ouderrelatie. Deze laatste mag dan wel barsten vertonen door de hoogopgelopen emoties en moeilijke context waarbinnen ze hun ouderrol dienen te vervullen, er moet te allen tijde vermeden worden dat deze, net als de partnerrelatie, onherstelbaar breekt.

In wat volgt, wordt onderzocht in welke mate de Belgische overheid haar rol naar behoren vervult in het waken over adequate conflicthantering van parentale ontvoeringen en breder, conflictueuze familiesituaties. Doelstelling daarbij is het leveren van inzichten om het proces van conflicthantering te optimaliseren. Het is namelijk de verantwoordelijkheid van de wetgevende en rechtsprekende actoren om te waken over de belangen van de betrokken kinderen. Idealiter treden de ouders op als belangenbehartigers van hun kinderen en houdt de overheid zich op de achtergrond. Wanneer ouders te veel verstrikt zijn in hun onderlinge strijd, zijn ze niet langer gepaste belangenvertegenwoordigers en neemt de rol van de overheid bijgevolg toe.

\section{Strijdende ouders vast in een tumultueus traject na een parentale ontvoering}

Een derde factor die de keuze voor de casus van parentale ontvoering verantwoordt, is het gegeven dat analyse van deze casus veel informatie verschaft over diverse methodes van conflicthantering. Het betrokken gezin doorloopt doorgaans een tumultueus traject waarbij de conflictpartijen zowel in aanraking komen met bemiddelings- als gerechtelijke procedures. In wat volgt, wordt een schets van het traject gegeven (zie ook figuur 1 aan het einde van dit artikel).

\section{Diverse rechterlijke tussenkomsten}

Vanuit juridisch-technisch oogpunt is internationale parentale ontvoering een complexe casus. Het fenomeen geeft in de Belgische context aanleiding tot het naast elkaar bestaan van twee procedures uit twee verschillende rechtstakken. In eerste instantie is er de burgerlijke procedure die erop gericht is de geschonden beslissing, die het omgangsrecht van beide wettelijke ouders regelt, te eerbiedigen. In tweede instantie is er de procedure die erop gericht is de ontvoerende ouder te straffen, gezien deze zich schuldig gemaakt heeft aan het misdrijf 'niet afgeven van kinderen', omschreven in artikel 432 Strafwetboek (Sw.). ${ }^{18}$ Het wordt omschreven als het misdrijf dat erin bestaat de rechterlijke beslissing niet

17 J. Willems, B. Appeldoor \& M. Goyens, Living together apart: scheiden als partners, samenleven als ouders, Tielt: Lannoo 2013.

18 Art. 432 Belgisch Strafwetboek. 
te respecteren die het recht op persoonlijk contact of het omgangsrecht van een van beide (wettelijke) ouders regelt.

Traditioneel wordt in de literatuur veel aandacht besteed aan het belang van het kind binnen de burgerlijke procedure. Binnen de strafprocedure blijft het daarentegen een onderbelicht thema. Het streven naar een kindvriendelijke justitie lijkt zich vooralsnog te beperken tot de tak van het burgerlijk recht. Nochtans zet het VN-Kinderrechtencomité aan tot een brede interpretatie van artikel 3 van het Internationaal Verdrag voor de Rechten van het Kind (IVRK), dat bepaalt dat de belangen van de kinderen de eerste overweging moeten vormen in alle procedures die hun aangaan. ${ }^{19}$ Conform deze interpretatie moet dit verdragsartikel ook in de strafprocedure worden gerespecteerd, nu de uitkomst van een vervolgingsbeslissing onbetwist een impact zal hebben op het leven van het betrokken kind. Wanneer teruggegrepen wordt naar het juridische parcours van de ouders, valt op dat dit reeds zijn aanvang kent voor de parentale ontvoering. Om zich te kunnen beroepen op de strafbaarstelling in artikel 432 Sw., moet namelijk sprake zijn van een geschonden burgerlijke beslissing inzake het verblijf van de kinderen. Deze rechterlijke beslissing is een constitutief element van het misdrijf 'niet afgifte van kinderen'. ${ }^{20}$ Dit betekent dat de ouders reeds een, weliswaar burgerlijke, procedure voor de (Belgische) familierechtbank achter de rug hebben, voorafgaand aan de ontvoering.

Nadat de ontvoering heeft plaatsgevonden, kan opnieuw een burgerlijke procedure opgestart worden. Deze procedure heeft tot doel de kinderen terug te brengen naar hun oorspronkelijke verblijfplaats. Juridische bases daarvoor zijn internationaal privaatrechtelijke instrumenten die de spoedige terugkeer moeten bewerkstelligen. Diverse verdragen en verordeningen werden opgesteld op niveau van de Verenigde Naties (en aanvullend de Haagse Conferentie), de Raad van Europa en de Europese Unie. ${ }^{21}$

19 Internationaal verdrag 20 november 1989 inzake de rechten van het kind opgemaakt te New York, B.S 17 januari 1992; UN Committee on the Rights of the Child (CRC) (2013). General comment No. 14 (2013) on the right of the child to have his or her best interests taken as a primary consideration (art. 3, para. 1), UN Doc. CRC/C/GC/14.

20 B. De Smet, B, Niet-afgifte van kinderen, in: A. Vandeplas \& P. Arnou (red.), Strafrecht en strafvordering. Artikelsgewijze commentaar met overzicht van rechtspraak en rechtsleer, Mechelen: Kluwer 2015.

21 Respectievelijk: Wet van 10 augustus 1998 houdende instemming met het verdrag betreffende de burgerlijke aspecten van internationale ontvoering van kinderen, opgemaakt te 's-Gravenhage op 25 oktober 1980, tot opheffing van de artikelen 2 en 3 van de wet van 1 augustus 1985 houdende de goedkeuring van het Europees Verdrag van Luxemburg betreffende de erkenning en de tenuitvoerlegging van beslissingen inzake het gezag over kinderen en betreffende het herstel van het gezag over kinderen, opgemaakt te Luxemburg op 20 mei 1980, BS 24 april 1999; Wet van 1 augustus 1985 houdende de goedkeuring van het Europees Verdrag van Luxemburg betreffende de erkenning en de tenuitvoerlegging van beslissingen inzake het gezag over kinderen en betreffende het herstel van het gezag over kinderen, opgemaakt te Luxemburg op 20 mei 1980, BS 11 december 1985; Verordening 2201/2003/EG van 27 november 2003 van de Raad betreffende de bevoegdheid en de erkenning en tenuitvoerlegging van beslissingen in huwelijkszaken en inzake de ouderlijke verantwoordelijkheid, en tot intrekking van Verordening nr. 1347/2000/ EG, P.B, L. 338, 23 december 2003. 
In de nasleep van de ontvoering kan ook een strafprocedure opgestart worden. Daar waar er voor de burgerlijke procedure een internationale grondslag aanwezig was, is dit niet het geval voor de strafprocedure. Er bestaat nergens een Europese verplichting tot strafbaarstelling van parentale ontvoering, wat de nodige moeilijkheden met zich meebrengt in het domein van het uitleverings- en overleveringsrecht. In België is ervoor gekozen de ontvoering strafbaar te stellen. Het dient onderstreept te worden dat de strafprocedure zich volledig los van de burgerlijke procedure ontwikkelt. De vraag rijst of er nood is aan een monitoringsmechanisme dat beide procedures op elkaar afstemt.

Het is onmiddellijk duidelijk dat deze talloze juridische tussenkomsten zich, na verloop van tijd, in een toenemende vijandige context zullen afspelen. Wanneer een strafprocedure wordt opgestart ten aanzien van de ontvoerende ouder, is het duidelijk dat samenwerking (tijdelijk) onmogelijk wordt.

\section{Diverse bemiddelingstrajecten}

Zoals eerder gezegd, wordt bij een parentale ontvoering een verblijfsbeslissing geschonden. Deze schending vormt de basis voor de bestraffing van de ontvoerende ouder. De oorspronkelijke verblijfsbeslissing dient een afdwingbaar karakter te hebben, welke in België tot stand komt door de formalisering ervan door de familierechtbank.

In de meeste gevallen volgt deze procedure voor de familierechtbank tot formalisering van de regeling na een gefaalde poging tot bemiddeling inzake het verblijf van de kinderen. In 2005 nam de Belgische wetgever namelijk het initiatief om rechtsprekende actoren de verplichting op te leggen alle ouders, betrokken in een wettelijke scheiding, te informeren over de mogelijkheid tot bemiddeling om tot een akkoord te komen. Bovendien nam huidig Belgisch minister van Justitie Koen Geens in 2018 duidelijke initiatieven om de alternatieve geschiloplossing hoog op de politieke agenda te plaatsen. Door de bemiddelingspoging nu verplicht te maken blijft het ultimum remedium karakter van gerechtelijke procesvoering behouden. Het principe van de vrijwilligheid van de bemiddeling werd daarmee wel van tafel geveegd. Hoewel vraagtekens geplaatst kunnen worden bij dit onderuithalen van de vrijwilligheid ${ }^{22}$ is het een goede zaak dat bemiddeling een steeds prominentere positie toegewezen krijgt in het Belgische juridische landschap voor het beslechten van diverse soorten conflicten. De eerste mogelijke bemiddeling vond dus, net zoals de eerste mogelijke juridische tussenkomst, plaats voorafgaand aan de ontvoering.

De tweede mogelijke bemiddeling behandelt het conflict na de ontvoering. Deze heeft tot doel te komen tot een overeenkomst over de mogelijke terugkeer van het kind. Op EU-niveau werd het Cross Border Mediation Network opgericht, dat bestaat uit een team gespecialiseerde bemiddelaars in grensoverschrijdende familiezaken. Hun netwerk breidt zich steeds verder uit, evenals hun streven om van deze grensoverschrijdende bemiddeling de prioritaire handelingswijze te maken bij parentale ontvoeringen. Tijdens deze methodiek, waarbij het belang van het

22 T. Wijnant, Verplichte doorverwijzing naar bemiddeling: we can lead a horse to water, but can we make it drink?, TMD 2018 (22) 2, p. 63-85. 
kind centraal staat, worden twee bemiddelaars aangesteld die de kenmerken van beide conflictpartijen zo goed als mogelijk spiegelen. Concreet wordt overeenkomst nagestreefd met betrekking tot geslacht, culturele, psychologische en taalkundige achtergrond, zodat de kans dat beide partijen zich goed vertegenwoordigd en belangrijker, goed begrepen voelen, gemaximaliseerd is. Deze cross-border mediaton bevindt zich uitdrukkelijk binnen de burgerlijke sfeer.

In de nasleep van een ontvoering kan daarnaast ook bemiddeling opgestart worden in de strafrechtelijke sfeer: de bemiddeling in strafzaken. Deze is sinds 1994 formeel ingeschreven in het Belgisch Wetboek van Strafvordering onder artikel 216 ter. $^{23}$ Sindsdien kan het openbaar ministerie kiezen voor deze vorm van buitengerechtelijke afhandeling, waardoor vermeden wordt dat de ontvoerende ouder verder doorstroomt in de strafrechtsketen. Argumenten daarvoor zijn te vinden in het waarborgen van het belang van het kind. Het is immers duidelijk dat vervolging van de ontvoerende ouder een belangrijke impact zal hebben op het kind. Paragraaf vier van de strafbepaling bepaalt dat een succesvol bemiddelingstraject resulteert in het verval van de strafvordering, waardoor een definitief einde komt aan de strafvervolging.

Samengevat is het opmerkelijk dat ouders maar liefst drie diverse bemiddelingstrajecten kunnen doorlopen hebben: de eerste tijdens het bepalen van de verblijfsregeling, de tweede wanneer geoordeeld wordt over de terugkeer en de derde in het kader van de mogelijke strafprocedure. Het dient onderstreept te worden dat meestal niet op eigen initiatief voor deze bemiddelingen gekozen wordt. De conflictpartijen moeten weliswaar instemmen, maar het aanbod tot instap in de bemiddeling komt op initiatief van de overheid. Gezien bereidwilligheid en intrinsieke motivatie belangrijke randvoorwaarden zijn voor bemiddeling, kunnen daarbij vragen gesteld worden.

\section{Kritische reflectie op het traject}

De voorgaande bespreking bracht het complexe traject in kaart. Enkele kritische reflecties zijn daarbij op hun plaats. De focust ligt daarbij voornamelijk op het gedeelte van het traject dat zich afspeelt na de ontvoering.

\section{Diverse methodieken doorkruisen de de-escalatie}

Eerst en vooral is het goed zich bewust te zijn van het feit dat het doorlopen van dit traject verschillende dynamieken op verschillende tijdstippen op gang zal brengen. Hoe verder ouders gevorderd zijn in het traject en hoe meer (tevergeefse) pogingen ze ondernomen hebben om tot een oplossing te komen, hoe dieper de motivatie om constructief samen te werken zal dalen. Met dit dalen van de motivatie daalt ook de waarschijnlijkheid dat een tussenkomst een afdoend antwoord zal bieden op het conflict.

Dit verder verstrikt geraken in het conflict heeft tot gevolg dat de kans dat bemiddeling soelaas biedt, daalt. De theorie van Glasl zal hierop verder ingaan. Deze 
dalende doeltreffendheid geldt echter ook voor de gerechtelijke tussenkomsten. Zich neerleggen bij, en conformeren aan, rechterlijke vonnissen wordt na escalatie van het conflict steeds moeilijker.

Bij elke nieuwe tussenkomst is het dan ook belangrijk het voorgaande traject in overweging te nemen. Vroege bemiddelingspogingen of rechterlijke tussenkomsten vinden plaats in een totaal andere context en worden vanuit een andere mindset gepercipieerd dan latere tussenkomsten in een reeds geëscaleerd conflict. Samenvattend is voorzichtigheid geboden bij het herhaaldelijk toepassen van de beide methodieken naast elkaar. Het gevaar dat beide hun doel volledig voorbijstreven of erger nog, elkaar ondergraven, wordt doorheen de tijd bijzonder groot.

\section{Cross-border mediation en verval van de strafuordering?}

Ten tweede kunnen vraagtekens geplaatst worden bij het feit dat een geslaagde burgerlijke bemiddeling een strafrechtelijke bemiddeling niet verhindert. Wanneer tijdens de cross-border mediation een overeenkomst werd bereikt, kunnen de partijen alsnog terechtkomen in een bemiddeling in strafzaken. Momenteel opereren beide rechtstakken autonoom van elkaar en streven ze ook diverse finaliteiten na. Daarom blijft het mogelijk dat de ene bemiddeling slaagt en de andere faalt. Het hoeft geen betoog dat wanneer de bemiddeling in strafzaken mislukt en overgegaan wordt tot een vervolging, deze de eerder bereikte overeenkomst uit de cross-border mediation alsnog kan doorkruisen. Met het doorkruisen van de overeenkomst wordt ook het belang van het kind ondergraven.

Om aan dit gebrek aan afstemming te remediëren, lijkt het aangewezen dat de bemiddelingstrajecten geïntegreerd of minstens gecoördineerd verlopen. De vraag of aan het succesvol beëindigen van een cross-border mediation niet dezelfde gevolgen kunnen gekoppeld worden als aan de bemiddeling in strafzaken, dringt zich op.

Tegenstanders van deze interpretatie naar analogie kunnen zich beroepen op argumenten die verwijzen het publieke karakter van een strafprocedure. De overheid voert de strafrechtelijke handhaving uit met het oog op het algemeen belang, wat impliceert dat private belangen in principe geen plaats krijgen. ${ }^{24}$ Toch zijn diverse argumenten te formuleren die verduidelijken dat het koppelen van een verval van de strafvordering aan de cross-border mediation enerzijds principiële voordelen heeft en anderzijds geen strafrechtelijke principes in gevaar brengt. Wat betreft de principieel filosofische argumenten, is een drietal elementen belangrijk. Ten eerste wordt het strafrecht wel eens benoemd als de welopgevoede dochter van de wraak. ${ }^{25}$ Deze metafoor maakt duidelijk dat, hoewel vermomd in een jasje van principes en moraliteit, het strafrecht nog steeds gebaseerd is op vergelding en daarom heel wat leed kan veroorzaken. In het vermijden van dit leed schuilt precies een eerste sterk argument. Ten tweede is het beter het conflict terug te geven aan de betrokkenen, waardoor de dader zelf verantwoordelijkheid kan dragen. Ten derde is het opmerkelijk dat mediation niet altijd als ondersteund

25 J. Dierx, Redactioneel: Mediation in strafzaken, Tijdschrift Conflicthantering 2016, 5(4). 
wordt ervaren door de betrokken partijen. De verklaring hiervoor schuilt in het kenmerk van onpartijdigheid. De bemiddelaar stelt zich meerzijdig partijdig op, wat impliceert dat de bemiddelaar niet onvoorwaardelijk jouw belangen verdedigt, in tegenstelling tot een advocaat in een gerechtelijke procedure. Het is net deze onpartijdige houding die het mogelijk maakt de belangen van de kinderen centraal te plaatsen.

Wat betreft de juridisch-technische argumenten, zijn eveneens enkele relevante punten aan te halen. Ten eerste moet nagegaan worden in welke mate het aanvaard wordt in de rechtstheorie en -filosofie dat het belang van bepaalde individuen, in casu de ontvoerde kinderen, uit de maatschappij gelicht wordt. ${ }^{26}$ Traditioneel en historisch is in de Belgische civil law rechtstraditie steeds weinig ruimte geweest voor een actieve positie van het slachtoffer in het strafproces. Toch biedt de huidige hervorming van het Belgisch strafrecht meer ruimte om de belangen van de kinderen een prominentere positie te geven. In het toekomstige artikel 26 van het nieuwe Strafwetboek zal worden bepaald dat de negatieve neveneffecten van een straf op de rechtstreeks betrokken personen, hun omgeving en de samenleving in rekening moeten genomen worden. ${ }^{27}$ In dit artikel schuilt een opportuniteit om de kinderen op explicietere wijze op te nemen. Ten tweede is het zo dat de essentiële rechtswaarborgen gewaarborgd blijven wanneer een verval van de strafvordering gekoppeld wordt aan de cross-border mediation. Eerst en vooral zal het principe van de proportionaliteit ten volle gerespecteerd worden. Traditioneel is het zo dat strafrechtsactoren weigerachtig staan tegenover het in overweging nemen van private belangen, gezien dit meestal impliceert dat een strengere bestraffing zal worden geëist. In deze casus daarentegen, wordt gepleit voor een wegvallen van de bestraffing, wat net de terughoudendheid kan wegnemen. Daarnaast kan een duidelijke bepaling, die stelt dat een succesvol beëindigde bemiddeling zal leiden tot verval van de strafvordering, voorkomen dat het legaliteitsprincipe uitgehold wordt. Tot slot wordt ook het principe van de subsidiariteit gewaarborgd. Het koppelen van een verval van de strafvordering aan de cross-border mediation laat toe het strafrecht als laatste redmiddel te gebruiken. Brede reflectie over de adequaatheid van het strafrecht als middel voor de behandeling van bepaalde familiale situaties is daarbij wenselijk. Ten derde vormt het ontbreken van een Europese verplichting tot strafbaarstelling van internationale parentale ontvoering een extra argument. De EU heeft door dit nalaten de deur opengelaten tot andere, constructievere afhandelingen van deze zaken, zoals bemiddeling.

26 M.S. Groenhuijsen, Afrondende en overkoepelende beschouwingen over het thema privatisering van het strafrecht, Ars Aequi 2013, 62(7/8), p. 606-614.

27 J. Rozie, D. Vandermeersch, J. De Herdt, M. Debauche \& M. Taeymans, Commissie voor de hervorming van het strafrecht. Voorstel van voorontwerp van boek I van het strafwetboek, Brugge: Die Keure 2017. 


\section{Toepassing van de inzichten van conflict(de)escalatie volgens Glasl op de casus van parentale ontvoering}

In wat volgt, wordt de conflicttheorie van Glasl gebruikt als vertrekpunt om de onderzoeksvraag te beantwoorden, met name: In welke mate kunnen de wijzen van conflictbeslechting - in de Belgische context - geoptimaliseerd worden zodat het belang van het kind gewaarborgd blijft?

Om een adequaat antwoord te bieden op deze vraag, is het nodig een inschatting te kunnen maken van de mate waarin ouders constructief invulling kunnen geven aan een bemiddeling of een juridische tussenkomst. Om deze inschatting objectief te ondersteunen wordt de theorie van de Weense politicoloog Friedrich Glasl gebruikt, die de verschillende stadia van een conflict kwalificeert en koppelt aan de mogelijkheden en manieren tot de-escalatie.

Zijn theorie vindt zijn oorsprong in de context van een arbeidssetting en wordt bijgevolg voornamelijk toegepast op organisaties en groepen. Desalniettemin is de theorie evenzeer toepasbaar op een gezin, dat kan beschouwd worden als een micro-organisatie.

\section{De gevaarlijke afdaling}

De conflicttheorie stelt dat intensifiëring van veel conflicten onbewust en ongewild optreedt. De escalatieladder, die bestaat uit negen treden, dient als metafoor voor deze conflictescalatie. Na elke afdaling van drie treden wordt een nieuwe fase bereikt. Partners betrokken in een gezonde relatie starten bovenaan de ladder maar door toenemend conflict belanden ze uiteindelijk in een sterk vijandige houding tegenover elkaar onderaan de ladder, in een situatie van totale oorlog. Tijdens deze afdaling bevinden zij zich achtereenvolgens in de rationele (treden één tot drie), de emotionele (treden vier tot zes) en de vechtfase (treden zeven tot negen).

Doorheen de afdaling verharden de standpunten en overschrijden de betrokkenen telkens kritische drempels die symbool staan voor een keerpunt. De drempels worden steeds groter en de wonden worden steeds dieper, wat genezing bijzonder bemoeilijkt. Het afdalen van elke nieuwe trede heeft gevolgen voor de handelingsmogelijkheden, bedoelingen en percepties die heersen bij de partijen. Elke trede heeft namelijk zijn eigen rationaliteit met andere geboden en verboden. ${ }^{28}$

Centrale doelstelling bij het de-escaleren van een conflict is om de vijandige houding te overstijgen en beide partijen de weg omhoog te wijzen op de ladder, waar een onderling constructieve verstandhouding opnieuw mogelijk is. Bovenaan de ladder is het mogelijk de focus alsnog te verleggen naar hun gemeenschappelijke doel: het welzijn van hun gezamenlijke kinderen.

Om deze weg te bewandelen is een verandering van mindset nodig, die geenszins vanzelfsprekend is. Glasl stelt dat conflictescalatie een pathologisch gebeuren is, waarbij slechts beperkte sturing mogelijk is. Dit fatalistische karakter heeft 
belangrijke implicaties voor de mogelijkheid tot de-escalatie. Centrale uitdaging is om de negatieve spiraalbeweging tijdig te doorbreken. ${ }^{29}$

De escalatieladder is bijzonder nuttig als diagnostische tool om te voorspellen of en hoe mensen kunnen aangesproken worden op hun verantwoordelijkheid als ouder. Het maakt duidelijk dat de manieren van conflicthantering afgestemd dienen te worden op de intensiteit van het conflict. ${ }^{30}$

\section{Vechten tot totaal verlies voor elkeen}

Doorheen de afdaling van de ladder wordt een destructieve interne logica gecreëerd die ervoor zorgt dat het conflict zijn eigen leven gaat leiden. De verklaring hiervoor ligt in de interne logica van een conflict, welke ervoor zorgt dat de oorzaak na verloop van tijd niet langer bij de afzonderlijke partijen ligt maar wel in de interactie die ze samen teweegbrengen. Glasl verwoordde dit treffend als: 'Eerst had ik een conflict, maar nu heeft het conflict mij.' ${ }^{31}$ In wat volgt, worden de drie fasen in het escalatieproces beschreven. Een schematische weergave is te vinden in figuur 2 (zie aan het einde van dit artikel).

\section{Rationele fase: win-win}

Kenmerkend voor de eerste fase is het gegeven dat de samenwerking tot nog toe primeert op de onderlinge strijd. ${ }^{32}$ Beide partijen zijn nog in staat een probleem co-operatief op te lossen. Hun gemeenschappelijke belang, in casu de gezamenlijke kinderen, is datgene wat de onderlinge verstandhouding nog de nodige fundamenten biedt. Niettegenstaande deze schijnbare vrede tussen beide partijen hebben spanningen, frustraties en tegenstellingen zich opgebouwd.

Op de trede 'verharding' percipiëren beide partijen hun standpunten als onderling onverenigbaar. Interacties met de ander worden als teleurstellend ervaren, waardoor het wederzijdse vertrouwen afneemt. Op de trede 'debat en polemiek' doet de manipulatieve argumentatiemethode zijn intrede. Bovendien breidt het conflict zich verder uit, voorbij een welomschreven aspect. De derde trede, 'geen woorden maar daden', is bereikt wanneer de andere partij niet langer geconsulteerd wordt voor het handelen. Het recht om gehoord te worden wordt hier volledig tenietgedaan. De ander wordt nu beschouwd als een expliciete concurrent en alles wordt eraan gedaan deze te weerhouden zijn doel te bereiken.

In deze rationele fase staan nog diverse vormen van conflicthantering open, waaronder zelfzorg, gespreksfacilitatie en professionele bemiddeling. Het conflict wordt daarbij op een constructieve manier gehanteerd, waardoor een verder dalen op de ladder alsnog voorkomen kan worden.

29 F. Glasl, Handboek conflictmanagement, Amsterdam: B.V Uitgeverij SWP 2015.

30 R. Melchers \& L. Stam, Systemische en positieve conflictoplossing, Tijdschrift voor conflicthantering 2014(1), p. 37-41. F. Glasl, The process of conflict escalation and roles of third parties, in: Conflict management and industrial relations, Dordrecht: Springer 1982, p. 119-140.

31 F. Glasl, Help! Conflicten: heb ik een conflict of heeft het conflict mij?, Zeist: Uitgeverij Christofoor 2001.

32 F. Glasl, Handboek conflictmanagement, Amsterdam: B.V Uitgeverij SWP 2015; F. Glasl, Help! Conflicten: heb ik een conflict of heeft het conflict mij?, Zeist: Uitgeverij Christofoor 2001. 


\section{Emotionele fase: win-verlies}

In deze tweede fase is het glashelder dat emoties volledig de bovenhand genomen hebben en alle rationaliteit naar de achtergrond is verdwenen. ${ }^{33}$ In deze fase worden morele oordelen gevormd, waarbij beide conflictpartijen gezichtsverlies willen bekomen bij de ander en hun eigen imago als tegengesteld aan dat van de ander willen voorstellen.

Op de vierde trede, 'imago en coalitie', nemen reputatie en integriteit belangrijke posities in. Het zijn nu niet langer de standpunten, maar wel de karakters die onverenigbaar zijn. De wens om de ander te straffen, weliswaar op een niet-formele manier, is constant aanwezig. De volgende neerwaartse stap situeert zich op de trede 'gezichtsverlies'. Op deze trede wordt de basiseer van de ander neergehaald in de publieke wereld. De laatste resten overgebleven ambiguïteit verdwijnen, waardoor de ander eenzijdig negatief wordt gepercipieerd en benoemd wordt als een duivel, een criminele en moreel corrupte figuur. De zesde trede is deze van 'dreigstrategieën en afpersing'. Waar op de vorige treden de gewenste bestraffing nog informeel verliep, heeft het conflict op dit moment een duidelijk openlijk karakter. Gevoelens van controleverlies en woede overheersen op dit moment alles. Tijdens de emotionele fase kan volgens Glasl enkel nog professionele bemiddeling soelaas bieden.

\section{Vechtfase: verlies-verlies}

De partijen zijn in deze laatste fase gevaarlijk diep afgedaald op de ladder. ${ }^{34}$ De enige bevrediging die op dit moment nog te halen valt, is het mee ten onder gaan van de vijand. Vanzelfsprekend betekent dit ook voor het kind, dat als wapen en prooi gebruikt wordt tijdens het gevecht, totaal verlies.

Op de zevende trede, 'beperkte vernietigingsslagen', worden bedreigingen omgezet in actie, waardoor het gevoel van veiligheid verdwijnt. Overleven en minder schade lijden dan de tegenpartij zijn nu de hoofddoelen. Verlies voor de een betekent automatisch winst voor ander. Op de trede 'versplintering, totale vernietiging' wordt getracht de basis van het bestaan van de tegenstander te vernietigen. Op de allerlaatste trede heerst totale oorlog. De wens tot zelfbehoud, die het langst bleef bestaan, verdwijnt nu ook. Tegen de prijs van de vernietiging van zichzelf én alle mogelijke slachtoffers, moet de ander ten onder gaan.

Het behoeft geen verdere uitleg dat de betrokken kinderen de eerste slachtoffers zijn die mee ten onder zullen gaan. Het belang van de kinderen wordt in deze vechtfase totaal miskend. Op de achtste trede is het duidelijk dat het kind geen plaats meer krijgt als actor, maar louter gereduceerd wordt tot speelbal, tot middel om het conflict op dramatische wijze op te drijven. Glasl stelt dat rechterlijke tussenkomst de enig resterende mogelijkheid is die in deze fase nog openstaat voor de partijen. 
Implicaties van de positie van de ouders op de ladder voor de handelingsmogelijkheden Wanneer de escalatieladder wordt toegepast op de casus van parentale ontvoering, komt een aantal belangrijke inzichten naar voor.

Een eerste mogelijkheid is dat de ouders zich voorafgaand aan de ontvoering nog hoog op de ladder bevinden. Gedurende hun breuk hebben zij de eerste twee treden naar beneden bewandeld. Op de derde trede komen de visies zo ver uit elkaar te liggen, dat een van beide ouders zich terugtrekt uit de coöperatie en het kind met zich meeneemt zonder consultatie van de achtergebleven ouder. Een daadwerkelijke ontvoering kan dus reeds plaatsvinden op de derde trede. Na de ontvoering dalen de ouders verder af, richting de emotionele fase. Daarbij kan de achtergebleven ouder een strafprocedure starten tegen de ontvoerende ouder. Deze actie kan ingegeven zijn uit allesoverheersende woede, die in deze fase het volledige conflict beheerst. De veroorzaker van het kwaad moet dan gestraft worden voor zijn verwerpelijke daden, liefst zo hard mogelijk. Het conflict ontspoort verder in de vechtfase, waar het kind sterk lijdt onder de situatie.

Een tweede mogelijkheid is dat de ouders reeds het merendeel of zelfs de volledige ladder afgedaald zijn in hun vechtscheiding voordat ook maar sprake is van een ontvoering. Dit scenario heeft een grote waarschijnlijkheidsgraad, gezien het daadwerkelijk vijandig handelen in de rationele fase meestal beperkte proporties aanneemt. Zelden zal het in de rationele fase al tot een ontvoering komen. Normaliter zijn de ouders op dat ogenblik nog in staat om het belang van de kinderen voorop te stellen. De ontvoering vindt in dit tweede scenario pas plaats tijdens de vechtfase.

Ongeacht de precieze situering van de ontvoering op de ladder, is het duidelijk dat de ouders na verloop van tijd gevaarlijk veel treden afgedaald zijn. De methode van conflicthantering zal dus hoe dan ook afgestemd moeten zijn op de context van het hoog opgelopen conflict.

De positie die de ouders innemen op de escalatieladder geeft veel relevante informatie over de potentiële slaagkansen van de diverse methodes van conflicthantering. Succes wordt daarbij gedefinieerd als het op zodanige wijze omgaan met het conflict, dat het belang van het kind optimaal gewaarborgd blijft. In onderstaande sectie worden de resultaten van de literatuurstudie inzake de toepassing van zowel bemiddeling als gerechtelijke procesvoering op geëscaleerd familiaal conflict onder de loep genomen.

\section{Adequate conflicthantering: strijden om rechtvaardigheid of onderhandelen over het onderwerp van de strijd?}

De theorie van Glasl heeft de dynamieken van conflictescalatie blootgelegd. In wat volgt, worden de dynamieken van conflictbeslechting geanalyseerd. De methodiek van gerechtelijke procesvoering wordt afgezet tegen en vergeleken met deze van de bemiddeling. Er wordt onderzocht in welke mate ze bruikbaar zijn in, en afgestemd zijn op, de casus van internationale parentale ontvoering. Uiteindelijk doel van deze bespreking en vergelijking is het komen tot best prac- 
tices in de afhandeling van complexe en intense familiale conflictsituaties op zo'n manier, dat de belangen van de kinderen gewaarborgd blijven.

\section{Dynamieken van procederen}

Gezien een geschonden burgerlijke verblijfsbeslissing een constitutief element is van het misdrijf 'niet afgifte van kinderen', heeft elk gezin waarbinnen ontvoerd wordt reeds een burgerlijke juridische tussenkomst achter de rug. Niet zelden raken de ouders vanaf dan gevangen in een vermoeiende procedurestrijd. ${ }^{35}$

Diverse auteurs stellen dat een uitspraak van justitie zelden leidt tot de-escalatie van een conflict. Eerder dan dat zal de positie van winnaar of verliezer formeel erkend worden. Een algemene kritiek op het actuele juridisch kader is dat er te sterk geredeneerd wordt vanuit ouderlijke rechten, terwijl eerder de rechten en de belangen van de kinderen centraal zouden moeten staan. Ontwikkelingspsychologen hebben erop gewezen dat al te vaak het kind als invuller van zijn eigen belang vergeten wordt. ${ }^{36}$

Onderzoek heeft zich vooralsnog voornamelijk toegespitst op het wetgevend en institutioneel kader in het licht van de gezags- en verblijfsregeling van kinderen na scheiding. In de huidige wetgeving is te lezen dat de voorkeur wordt gegeven aan de gezamenlijke uitoefening van het ouderlijk gezag in de vorm van verblijfsco-ouderschap of bilocatie. ${ }^{37}$ Deze formulering heeft tot gevolg dat beide ouders een vernauwde blik hebben op hun rechten en zo het welzijn van hun kinderen uit het oog verliezen. Door het wettelijk naar voor schuiven van bilocatie als heilige graal, faalt de overheid in haar verplichting het conflict te de-escaleren in het belang van de betrokken kinderen. Meer nog, dergelijke bepalingen werken conflictverhogend. ${ }^{38}$ Daarnaast is het opmerkelijk dat voorbijgegaan werd aan het gegeven dat de ouders die voor de familierechtbank een verzoekschrift neerleggen net diegenen zijn die de kenmerken missen welke noodzakelijk zijn voor een goed functionerende bilocatie: wederzijds respect, vertrouwen en flexibiliteit. ${ }^{39}$ Het is minstens verontrustend te zien dat uitgerekend deze partijen, die volledig verstrikt zijn in een destructieve interactie, onderhevig worden aan het actuele institutionele kader. Ze missen de noodzakelijke attitudevoorwaarden om het vonnis constructief in te vullen. Er kunnen aldus belangrijke vraagtekens worden

35 B.E.S. Chin-A-Fat \& M.J. Steketee, Evaluatie experimenten scheidings- en omgangsbemiddeling, Tijdschrift voor familie-en jeugdrecht 2001(11), p. 296-302.

36 A.L. James, Children, the UNCRC, and family law in England and Wales, Family court review 2008, 46(1), p. 53-64; M.H. Ottosen, In the name of the father, the child and the holy genes: Constructions of 'the child's best interest' in legal disputes over contact, Acta Sociologica 2006, 49(1), p. 29-46.

37 Wetsvoorstel tot regeling van de gevolgen van het gelijkmatig verdeelde verblijf van kinderen bij beide ouders na scheiding, Parl.St. Senaat, nr. 5-498/1, 16/11/2010; Memorie van toelichting, Parl.St. Kamer, nr. 51-1673/001, 17/03/2005.

38 C.R. Mol \& U. Cerulus, U, Studiedag 'Gezinstransities vanuit het perspectief van de kinderen'. Family and Law 2016(2).

39 J.E. Mcintosh, Legislating for shared parenting: Exploring some underlying assumptions, Family Court Review 2009, 47(3), p. 389-400.; I. Pasteels, P. Bracke, D. Mortelmans, K. Matthijs, J. Van Bavel \& C. Van Peer, Scheiden in meervoud: over partners, kinderen en grootouders, Leuven: Acco 2013. 
geplaatst bij het huidige wettelijke kader, gezien dit dynamieken op gang brengt die aanzetten tot procederen.

Zoals eerder verduidelijkt, kan de ontvoering zelf nog aanleiding geven tot zowel een burgerlijke als een strafrechtelijke procedure. Zoals eerder vermeld, is het daarbij belangrijk stil te staan bij de positie van de ouders op de escalatieladder. Hun positie is doorgaans verontrustend laag en impliceert dat zij zich nog moeilijker dan voorheen zullen conformeren aan een vonnis.

Er dient opgemerkt te worden dat de-escalatie niet altijd het primaire doel is van een rechterlijke tussenkomst. Toch is het belangrijk om te handelen vanuit het belang van het kind, voor wie daling van het conflict een positief effect heeft.

De paradox van het strijden en procederen om rechtvaardigheid is hier opvallend. In de vechtfase proberen de conflictpartijen vooral recht te halen, wat niet gelijk staat aan het bekomen van rechtvaardigheid. Strijden om rechtvaardigheid is immers een contradictio in terminis. De term adversary process, gebruikt in de Engelstalige literatuur voor de traditionele procesvoering, betekent letterlijk vertaald 'tegenstandersproces'. Dit wijst erop dat het juridische systeem gebaseerd is op geformaliseerde concurrentie. Door het procederen kunnen bestaande conflicten aangewakkerd worden en nieuwe veroorzaakt worden. ${ }^{40}$ Door de oprichting van de gespecialiseerde familierechtbanken in België is enige nuancering op zijn plaats. Toch kan niet voorbijgegaan worden aan deze negatieve dynamieken die, zeker zonder gespecialiseerde rechtbank, vrij spel krijgen binnen een gerechtelijke afhandeling. ${ }^{41}$

\section{Dynamieken van bemiddeling}

De aanname dat traditionele gerechtelijke procesvoering dergelijke negatieve dynamieken op gang brengt, lag mede ten grondslag aan het promoten van alternatieve manieren van conflictafhandeling. Sindsdien is veel inkt gevloeid over de zin en onzin van mediation in vechtscheidingszaken. Deze vorm van geschillenbeslechting is een gestructureerd en vertrouwelijk proces, waarbij de partijen zich vrijwillig laten bijstaan door een bemiddelaar die, vanuit een meerzijdig partijdige houding, een akkoord tussen beide partijen tracht te bereiken.

Het is duidelijk dat bemiddeling de laatste jaren hoog op de politieke agenda staat. De vraag rijst of de populariteit van bemiddeling ingegeven is vanuit een evidence-based denken of eerder opportunistisch aangewend wordt als middel om aan de gerechtelijke achterstand tegemoet te komen. Onderzoek kampt vaak met het selectie-effect, gezien volledige randomisatie zelden mogelijk is in vergelijkende onderzoeken. Om die reden wordt vaak getwijfeld aan de methodologische waarde van empirische resultaten.

40 R.E. Emery, D. Sbarra \& T. Grover, Divorce mediation: Research and reflections, Family Court Review 2015, 43(1), p. 22-37.

41 P. Blomqvist \& M. Heimer, Equal Parenting when Families Break Apart: Alternating Residence and the Best Interests of the Child in Sweden, Social Policy \& Administration 2016, 50(7), p. 787-804; K. Kressel, M. Lopez-Morillas, J. Weinglass \& M. Deutsch, Professional intervention in divorce: A summary of the views of lawyers, psychotherapists, and clergy, Journal of divorce 1978, 2(2), p. 119-155. 
De dynamiek van bemiddeling kenmerkt zich als informeel en coöperatief, waardoor deze in schril contrast staat met de context waarbinnen juridische procesvoering plaatsvindt. Uiteindelijk doel is het opnieuw mogelijk maken van parallel maar complementair ouderschap. Om dit te realiseren moet een andere realiteit worden geïntroduceerd binnen het ouderpaar, naast de strijdrealiteit die de interactie volledig beheerst. Onderzoek heeft aangetoond dat dit de schadelijke effecten van een scheiding voor de betrokken kinderen significant reduceert. Samengevat blijkt de meerwaarde van bemiddeling uit het dalen van ouderlijk conflict, de betere naleving van afspraken en het opstarten van minder vervolgprocedures. ${ }^{42}$ Om terug te komen op de concentrische cirkels van Wiewauters, speelt bemiddeling een belangrijke rol in de stretchzone. Het doel van bemiddeling is immers om te voorkomen dat mensen in de paniekzone terechtkomen of erin blijven steken. De vraag rijst opnieuw of binnen de casus van parentale ontvoering de ouders al niet te ver zijn afgedwaald/afgedaald in hun onderlinge conflict, mede door de voorafgaande juridische tussenkomst inzake de verblijfsregeling.

\section{Paradox in visies leidt tot noodzaak aan complementariteit}

Uit wat voorafging, werd reeds duidelijk dat het formuleren van een rechtvaardig antwoord op parentale ontvoering geenszins een sinecure is. Om dat antwoord van de noodzakelijke wetenschappelijke fundamenten te voorzien, wordt de state of the art in de literatuur inzake vechtscheidingen gepresenteerd, met het oog op toepassing ervan op de casus van parentale ontvoering.

Deze state of the art brengt een allerminst eenduidige visie naar voor. Centrale conclusie is dan ook dat het matchen en sequentiëren van diverse methodieken noodzakelijk is voor het bekomen van een optimaal resultaat. Hoewel dit idee van complementariteit niet nieuw is, ${ }^{43}$ werd het tot nog toe nog nooit in de voorgestelde vorm toegepast. Het huidige onderzoek heeft zich vooralsnog voornamelijk gefocust op het analyseren van de adequaatheid van bemiddeling voor diverse types van partners verwikkeld in een scheiding. ${ }^{44}$

\section{Vechtende ouders en een vonnis: een goed of een gedoemd huwelijk?}

Enerzijds is er een strekking in de literatuur, met Glasl als autoriteit, die duidelijk aantoont dat bemiddeling geen soelaas meer biedt in een te ver geëscaleerd conflict. De hoogopgelopen emoties en irrationaliteit belemmeren de bemiddelingsmethodieken, waardoor enkel nog een rechterlijke tussenkomst mogelijk is. Bemiddeling gaat er, in casu verkeerdelijk, van uit dat ouders nog in staat zijn

42 A. Buysse \& M. Renders, De impact van scheiding op kinderen: knelpunten gekoppeld aan de nieuwe wetgeving, Tijdschrift voor Jeugdrecht en Kinderrechten 2007/3, p. 147-151.

43 R.J. Fisher \& L. Keashly, The potential complementarity of mediation and consultation within a contingency model of third party intervention, Journal of Peace Research 1991, 28(1), p. 29-42.

44 O. Cohen, A. Luxenburg, N. Dattner \& D.E. Matz, Suitability of divorcing couples for mediation: A suggested typology. American Journal of Family Therapy 1999, 27(4), p. 329-344; K. Kressel, N. Jaffee, B. Tuchman, C. Watson \& M. Deutsch, A typology of divorcing couples: Implications for mediation and the divorce process, Family Process 1980, 19(2), p. 101-116. 
gezamenlijk afspraken te maken. De kans op escalatie neemt echter toe wanneer ouders voortdurend moeten communiceren over datgene waar het meeste strijd over bestaat: het winnen of verliezen van de kinderen. ${ }^{45}$

Anderzijds hebben auteurs ook aangetoond dat een rechterlijk vonnis evenmin een toereikende oplossing biedt. Integendeel, het kan het conflict verder opdrijven. Zoals eerder verduidelijkt, heeft het huidige wetgevende en institutionele kader waarbinnen de rechterlijke macht dient te opereren, een negatieve impact op de conflictdynamiek. In deze fase wordt het vonnis van de rechter door een van de partijen ervaren als 'onrechtvaardig' en ziet die dit als een reden om de strijd verder te zetten.

De balans is moeilijk op te maken. Voorzichtigheid is geboden bij het verkeerd interpreteren van de inzichten van Glasl. Het gebruikmaken van de escalatieladder mag geenszins een vrijgeleide zijn voor het niet in overweging nemen van bemiddeling, met het loutere excuus dat deze geen slaagkansen heeft, gezien de conflictpartijen tot de vechtfase zijn afgedaald. ${ }^{46}$ Enerzijds werd reeds aangevoerd dat de ontvoering reeds kan plaatsvinden op de derde trede, die zich nog in de rationele fase bevindt. Anderzijds kan bemiddeling nog steeds een meerwaarde bieden in de emotionele en zelfs de vechtfase wanneer deze zich focust op de ouderrelatie en niet op de partnerrelatie. Het is cruciaal een onderscheid te maken tussen beide relatieniveaus van de conflictpartijen.

Toch kan men niet omheen de eerste strekking die stelt dat bemiddeling zelden tot het verhoopte resultaat leidt. Deze paradox in onderzoeksresultaten en wetenschappelijke inzichten is bijzonder interessant. De vraag hoe een familieconflict, zoals die zich aandient bij een parentale ontvoering, dan wel moet behandeld worden, blijft tot nog toe onbeantwoord, maar dringt zich alsmaar sterker op.

\section{Complementaire aanpak essentieel}

Centrale conclusie van deze bijdrage is dat de afhandeling van ontvoeringszaken geoptimaliseerd kan worden aan de hand van een complementaire aanpak. De basis voor de complementariteit wordt geboden door de dubbele rol die de conflictpartijen opnemen: enerzijds deze van ex-partner en anderzijds deze van ouder.

Wat betreft de eerste rol, is het duidelijk dat het proberen de-escaleren van deze relatie vaak noch mogelijk, noch wenselijk is. Deze gebroken partnerrelatie is volledig vastgelopen en kenmerkt zich door heel wat negatieve emoties. In het licht van deze inzichten dient de methodiek van gerechtelijke procesvoering ingezet te worden binnen deze relatie. sociale professionals. Family \& Law 2017/2; V. Roseby \& J.R. Johnston, Children of Armageddon: Common developmental threats in high-conflict divorcing families, Child and Adolescent Psychiatric Clinics 1998, 7(2), p. 295-309; T. Geurts, I.D.A. Sportel, E.T. Beenakkers \& F.N. Arikan, Voorkomen van vechtscheidingen 2015; E. Spruijt \& H. Kormos, Opzet van het boek, in: Handboek scheiden en de kinderen, Houten: Bohn Stafleu van Loghum 2010, p. 22-28.

46 J. Bijlsma, Mediation in strafzaken als bron van moraliteit, Tijdschrift voor Conflicthantering 2016, 11(5), p. 24-28. 
Wat betreft de tweede rol dient bemiddeling op de voorgrond te komen. De reden waarom bemiddeling vaak mislukt, is net omdat de focus verkeerdelijk op de communicatie tussen de strijdende partners ligt. Het kind komt daarmee geen stap verder en vaak bouwen frustraties en teleurstellingen zich op. Het is daarom noodzakelijk de focus te verleggen naar de ouderrol die ze vervullen ten aanzien van hun kinderen. Bemiddeling kan ouders helpen constructief invulling te geven aan hun gedeeld ouderschap. De uitdaging daarbij is om de brokken te lijmen en de relatie niet te laten breken, zoals gebeurd is met de partnerrelatie. Het is beter bemiddelend aan de slag te gaan met beide ouders afzonderlijk wanneer de partijen te diep zijn afgedaald.

Samengevat zal een rechterlijke tussenkomst voor beide partners waarschijnlijk een noodzakelijk kwaad zijn. Bemiddeling kan wel een aanvullende meerwaarde bieden wanneer deze zich focust op hun rol als ouders, die hoe dan ook samen voortgezet moet worden. Op die manier gefocust, staat het belang van het kind centraal en worden de tevergeefse pogingen tot een algehele verzoening achterwege gelaten. De focus dient enkel te liggen op het gedeeld ouderschap, als middel om uit de scheidingsimpasse te geraken.

De meest recente literatuur pleit dan ook voor een innovatieve aanpak van vechtscheidingen, die vertrekt vanuit vijf gecombineerde bouwstenen: 1) parallel ouderschap is nodig om conflicten te vermijden. Coöperatief ouderschap, gekenmerkt door onderling overleg, is niet langer opportuun; 2) focus op het versterken van de ouder-kindrelaties; 3) het mobiliseren van het netwerk, dat het gezin kan helpen evolueren van de stress- naar de stretch- en comfortzone; 4) kinderen moeten rechtssubjecten worden: actieve dragers van rechten en plichten. Zo worden ze uit de schaduw, waar ze louter als passief rechtsobject beschouwd werden, gehaald; 5) het inzetten van psycho-educatie en coaching voor het waken over het blijvende positieve verloop van het traject. ${ }^{47}$ Deze bevindingen kunnen perfect naar analogie toegepast worden op de casus van internationale parentale ontvoering.

Deze aanpak maakt het mogelijk dat justitie en hulpverlening niet langer naast elkaar werken, maar elkaar versterken. Om het met een metafoor van Wiewauters te duiden: justitie biedt de grenzen waarbinnen gehandeld moet worden, maar vaak heeft een gezin naast grenzen ook nood aan hulp bij het invullen van de complexe situatie.

\section{Conclusie: naar een adequate conflicthantering door de overheid in zaken van parentale ontvoering}

Deze bijdrage heeft enkele inzichten aangereikt die uitnodigen kritisch te reflecteren over de verantwoordelijkheid van de overheden in het kiezen voor de adequate methodes van conflicthantering.

47 PXL Hogeschool. PXL-onderzoekers werken aan innovatieve methodiek voor aanpak van hoogconflictueuze echtscheidingen 2018, geraadpleegd op 26 december 2018. 
Enerzijds is het betwijfelbaar of de overheid met het huidige wetgevende en juridische kader de juiste prioriteiten gesteld heeft, in het licht van de belangen van de betrokken kinderen. De strijddynamiek zal immers niet gecounterd maar eerder bevestigd worden in een traditionele procesvoering voor de rechtbank. Anderzijds werd aangetoond dat een conflict dat geëscaleerd is tot in de vechtfase de bemiddelingsmethodiek bijzonder sterk bemoeilijkt.

De belangrijkste aanbeveling is dan ook te voorzien in maatwerk wat betreft de aanpak van parentale ontvoering. ${ }^{48}$ Conflictbegeleiders moeten zich te allen tijde bewust zijn van de positie van ouders op de escalatieladder en de implicaties van hun positie voor de (on)mogelijkheid tot de-escalatie. Bovenaan de ladder zijn nog talloze manieren van conflicthantering mogelijk. Bemiddeling krijgt meer kansen en er zal ook constructiever omgegaan worden met een rechterlijk vonnis. De belangrijkste taak van de overheden voor de toekomst is dan ook om volop in te zetten op de preventie van parentale ontvoering. Deze investering zal rendabeler zijn dan het investeren in methodes van conflictbeslechting. Hoe hoger op de ladder, hoe sneller, makkelijker en beter een overeenkomst kan gevonden worden. Het voorkomen van een escalatie is gemakkelijker dan het trachten de-escaleren van een conflict.

Tot slot is het interessant de dualiteit tussen procesvoering en bemiddeling niet langer te beschouwen als paradoxaal, maar als twee complementaire methodieken. Daar waar procesvoering eerder gebaseerd is op vertrouwen in de overheid, baseert bemiddeling zich op vertrouwen in elkaar. Het is duidelijk dat tussen de partners vertrouwen plaats heeft gemaakt voor wantrouwen en de tussenkomst van een rechter noodzakelijk kan zijn. Het is niet wenselijk de conflictpartijen te proberen dichter naar elkaar toe te brengen. Het trachten herstellen van het vertrouwen in elkaar als ouders is echter wél wenselijk. Het is uitgerekend deze factor die garant zal staan voor het herstellen van het welzijn van het betrokken kind. Het bereiken van deze constructieve invulling van gezamenlijk ouderschap vanuit onderling vertrouwen, is net datgene waarvoor bemiddeling een absolute meerwaarde biedt.

De wijze waarop de toepassing van deze methodes verwezenlijkt kan worden binnen de juridische setting dient daarom onderwerp te zijn van toekomstig wetenschappelijk onderzoek. Een weloverwogen kader is noodzakelijk om ervoor te waken dat ook de bemiddelingsmethodiek de juiste klemtonen legt en zo contraproductieve effecten vermijdt. Alleen op die manier kan de overheid haar rol als belangenvertegenwoordiger naar behoren vervullen. 


\section{Figuur 1 Escalatieladder van Glasl}
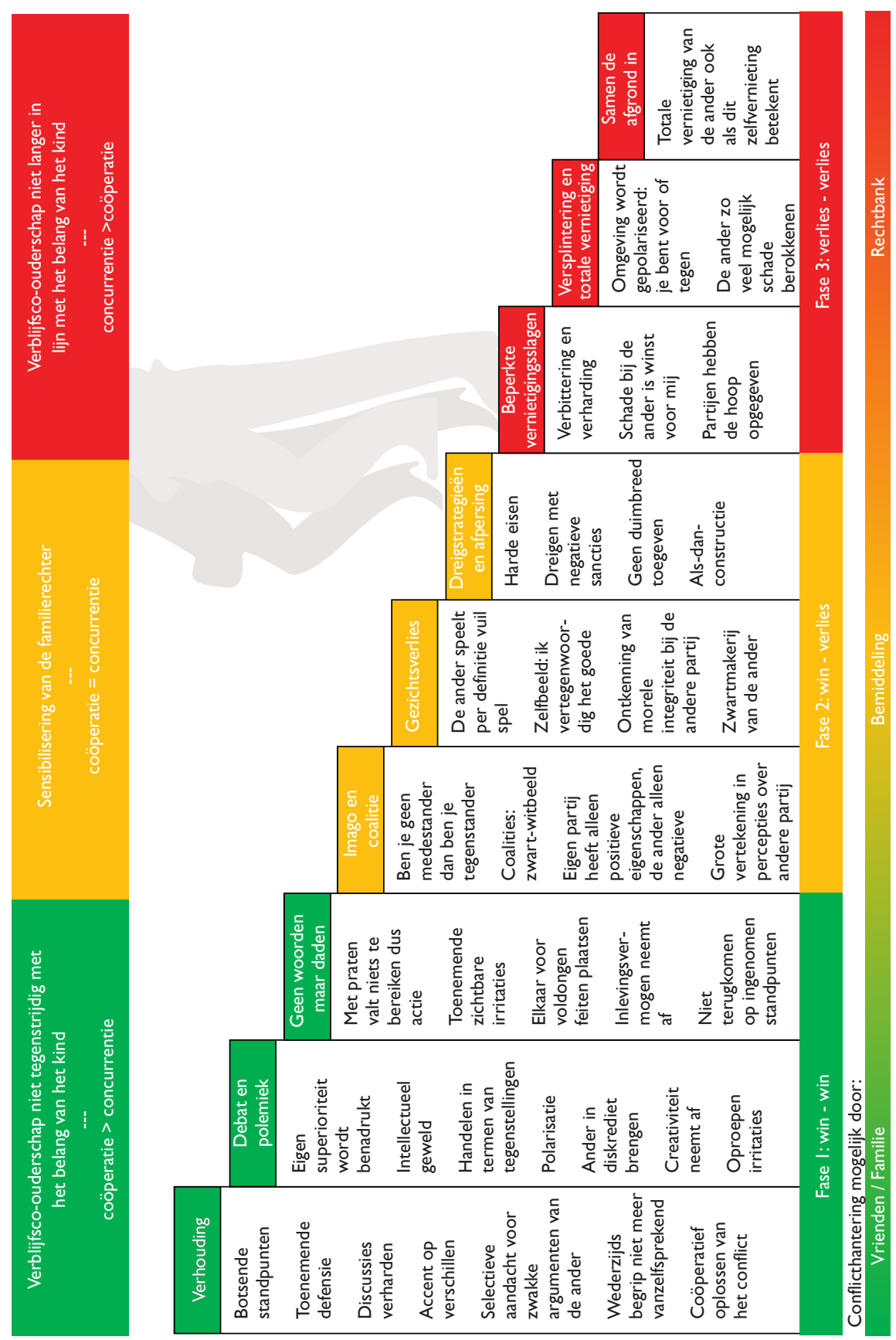
Figuur 2 Traject van ouders in casus internationale parentale ontvoering

Ouderlijk conflict

Methoden van conflicthantering

\section{BEMIDDELING}

Eerste burgerlijke bemiddeling inzake het bereiken van overeenkomst over de verblijfsregeling van de kinderen na scheiding

Tweede burgerlijke bemiddeling (cross-border mediation) inzake terugkeer van de kinderen naar de oorspronkelijke verblijfsplaats na ontvoering

Bemiddeling in strafzaken naar aanleiding van het instellen van de strafvervolging ten aanzien van de ontvoerende ouder

\section{RECHTERLIJKE} TUSSENKOMST

$\mathrm{Na}$ gefaalde bemiddelingspoging een vonnis van de familierechter over de verblijfsregeling van de kinderen na scheiding

\section{ONTVOERING}

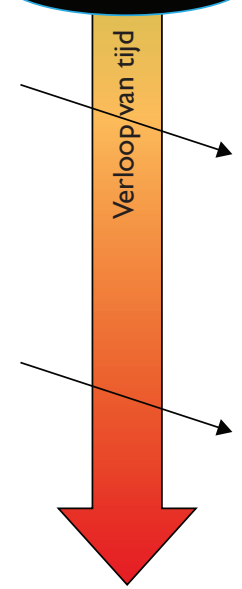

$\mathrm{Na}$ gefaalde cross-border

mediation een vonnis van de bevoegde rechtbank inzake de terugkeer van de kinderen

$\mathrm{Na}$ gefaalde bemiddeling in strafzaken eventueel een strafvonnis ter bestraffing van de ontvoerende ouder 